\title{
5-Azacytidine induces changes in electrophysiological properties of human mesenchymal stem cells
}

\author{
Bartosz Balana ${ }^{1,3}$, Cecilia Nicoletti ${ }^{1}$, Ihor Zahanich ${ }^{1}$, Eva M Graf ${ }^{1}$, Torsten Christ $^{1}$, Sabine Boxberger ${ }^{2}$, \\ Ursula Ravens $^{1}$ \\ ${ }^{1}$ Department of Pharmacology and Toxicology, ${ }^{2}$ Medical Clinic I, Medical Faculty, Dresden University of Technology, Fetscherstr. \\ 74, D-01307 Dresden, Germany
}

Previously, mouse bone marrow-derived stem cells (MSC) treated with the unspecific DNA methyltransferase inhibitor 5-azacytidine were reported to differentiate into cardiomyocytes. The aim of the present study was to investigate the efficiency of a similar differentiation strategy in human mononuclear cells obtained from healthy bone marrow donors. After 1-3 passages, cultures were exposed for $24 \mathrm{~h}$ to 5 -azacytidine $(3 \mu \mathrm{M})$ followed by 6 weeks of further culture. Drug treatment did not induce expression of myogenic marker MyoD or cardiac markers Nkx2.5 and GATA-4 and did not yield beating cells during follow-up. In patch clamp experiments, approximately $10-15 \%$ of treated and untreated cells exhibited L-type $\mathrm{Ca}^{2+}$ currents. Almost all cells showed outwardly rectifying $\mathrm{K}^{+}$currents of rapid or slow activation kinetics. Mean current amplitude at $+60 \mathrm{mV}$ doubled after 6 weeks of treatment compared with time-matched controls. Membrane capacitance of treated cells was significantly larger than in controls 2 weeks after treatment and remained high after 6 weeks. Expression levels of mRNAs for the $\mathrm{K}^{+}$channels Kv1.1, Kv1.5, Kv2.1, Kv4.3 and KCNMA1 and for the $\mathrm{Ca}^{2+}$ channel $\mathrm{Ca}_{\mathrm{v}} 1.2$ were not affected by 5 -azacytidine. Treatment with potassium channel blockers tetraethylammonium and clofilium at concentrations shown previously to inhibit rapid or slowly activating $\mathrm{K}^{+}$currents of hMSC inhibited proliferation of these cells. Our results suggest that despite the absence of differentiation of hMSC into cardiomyocytes, treatment with 5 -azacytidine caused profound changes in current density.

Cell Research (2006) 16:949-960. doi: 10.1038/sj.cr.7310116; published online 12 December 2006

Keywords: human mesenchymal stem cells, 5-azacytidine, cardiac differentiation, outward $\mathrm{K}^{+}$currents

\section{Introduction}

Due to their potential to differentiate into various cell types of adult tissues, bone marrow-derived human mesenchymal stem cells (hMSC) play an increasing role as a source of cells for regenerative medicine [1]. After myocardial infarction cardiac muscle possesses only limited

\footnotetext{
${ }^{3}$ Present address: The Salk Institute for Biological Studies, 10010 North Torrey Pines Road, La Jolla, CA 92037, USA. Tel: + 18584534100 Ext. 1681; E-mail: balana@salk.edu Correspondence: Ursula Ravens Tel: +49 351 4586300; Fax: +49 351 4586315;

E-mail: ravens@rcs.urz.tu-dresden.de

Received, 5 August 2006; revised, 17 October 2006; accepted, 14 November 2006; published online 12 December 2006
}

ability to regenerate and therefore bone marrow cells have been used in numerous attempts to support tissue repair both in animals and humans [2-5]. When cultured in vitro, hMSC readily differentiate into adipocytes, osteoblasts or chondrocytes under appropriate conditions [6]. 5-Azacytidine interferes with DNA methylation and was shown to induce mouse $10 \mathrm{~T} 1 / 2$ fibroblasts to differentiate into skeletal myoblasts by reactivation of the transcription of silenced genes including MyoD [7, 8]. After treatment with the drug, immortalized murine bone marrow-derived stromal cells differentiated into cardiomyocytes of various excitation properties [9] similar to the results obtained in cardiomyocytes derived from multipotent embryonic stem cells [10-12]. However, conflicting results have been published with respect to MSC from other species. In rat MSC, 5 -azacytidine was ineffective in promoting cell expansion 
or differentiation into cardiomyocytes [13], whereas other studies have claimed to obtain cardiomyocytes from $\mathrm{hMSC}$ following induction with the drug $[14,15]$.

Here we investigated whether 5-azacytidine would induce cardiomyocyte differentiation in hMSC after being subcultured one to three times. Cardiac differentiation, as evidenced by expression of early (sarcomeric $\alpha$-actinin), intermediate (myosin heavy chain) and late (cardiac troponin T) marker proteins of cardiomyocytes, could not be detected. However, delayed outwardly rectifying $\mathrm{K}^{+}$ currents were increased 6 weeks after 5-azacytidine treatment. Some of the results have been reported previously in a meeting abstract [16].

\section{Materials and Methods}

\section{Donors}

Bone marrow samples were obtained from healthy donors, all of whom gave their informed, written consent. The study was approved by the local ethics committee and all procedures with hMSC were performed according to the Declaration of Helsinki [17].

\section{Preparation of stem cells and culture conditions}

The bone marrow samples were collected at the Bone Marrow Transplantation Center of the University Hospital Carl Gustav Carus, Dresden, and hMSC were isolated and cultured as described previously [18]. Briefly, an aliquot from bone marrow aspirate diluted with phosphate-buffered saline (PBS) with $0.5 \%$ human serum albumin (HSA) was layered over a Percoll solution $(d=1.073 \mathrm{~g} / \mathrm{ml}$, Biochrom, Germany) and centrifuged at $900 \times g$ for $30 \mathrm{~min}$.

Mononuclear cells at the interface were recovered, washed twice in PBS-HSA and seeded into $75 \mathrm{~cm}^{2}$ flasks containing DMEM-low glucose supplemented with $2 \mathrm{mM}$ GlutaMAX ${ }^{\mathrm{TM}}$ (all from Gibco Invitrogen, UK) and 10\% fetal calf serum (Biochrom, Germany). The medium was completely changed after $48 \mathrm{~h}$. Automatically counted cells were maintained in a humidified atmosphere at $5 \% \mathrm{CO}_{2}$ and $37{ }^{\circ} \mathrm{C}$ until reaching $90 \%$ confluence. During subsequent passages cells were replated at a density of 5000 cells $/ \mathrm{cm}^{2}$ [19]. From second passage on, the culture medium was additionally supplemented with $100 \mathrm{U} / \mathrm{ml}$ penicillin and $100 \mu \mathrm{g} / \mathrm{ml}$ streptomycin. Aliquots of different passages were used for flow-cytometric characterization of the cells (FACScalibur 3CS, Becton Dickinson, CA, USA).

\section{Western blotting}

Cultures of hMSC or P19 (mouse embryonic carcinoma cell line) were washed with PBS and cells homogenized in Kranias buffer (30 mM Tris, 5 mM EDTA, $30 \mathrm{mM} \mathrm{NaF,} \mathrm{3 \%} \mathrm{SDS,} \mathrm{10 \%} \mathrm{glycerol).}$ Total protein content was determined using the Amido Black method [20]. Protein extracts were run on a 10\% SDS-PAGE gel ( $80 \mu \mathrm{g}$ total protein from hMSC and $8 \mu \mathrm{g}$ from P19) and blotted onto a nitrocellulose membrane (BioTrace ${ }^{\circledR}$ NT, PALL, FL, USA). Membranes were blocked in Tris-buffered-saline with $1 \%$ milk powder and probed overnight with anti-Oct3/4 antibody (clone C-10, Santa Cruz Biotechnology, CA, USA) diluted 1:200. Membranes were washed, probed with secondary antibody (anti-mouse sheep whole IgG antibody conjugated with horseradish peroxidase, Amersham Pharmacia Biotech, UK) diluted 1:500 and detected by chemiluminescence.
Effects of 5-azacytydine and ion channel blockers on cell cultures

Cell viability (hence cell number) was determined in 96-well plates using the colorimetric MTT (3-(4,5-dimethylthiazol-2)-2,5 diphenyltetrazolium bromide) assay (Roche Diagnostics, Switzerland) according to the manufacturer's protocol. Briefly, 5-azacytidine or ion channel blockers (tetraethylammonium (TEA), 4-aminopyridine (4-AP) clofilium or iberiotoxin) were added at the indicated concentrations. After $24 \mathrm{~h}$ (in case of 5-azacytidine) or $7 \mathrm{~d}$ (for ion channel blockers) $10 \mu \mathrm{l}$ of MTT labelling agent $(5 \mathrm{mg} / \mathrm{ml})$ was added to each well and plates were incubated for $4 \mathrm{~h}$ at $37^{\circ} \mathrm{C}$. The resulting formazan crystals were dissolved by addition of $100 \mu \mathrm{l}$ of solubilization reagent, followed by overnight incubation at $37^{\circ} \mathrm{C}$. Absorbances at $595 \mathrm{~nm}$ were determined by microplate reader (anthos HTIII, Anthos Labtec Instruments $\mathrm{GmbH}$, Austria). Results were normalized to untreated cultures (i.e. 100\% survival or inhibited growth).

\section{Recording of ion currents}

Membrane currents were measured in the whole-cell configuration of the patch clamp technique at $21-23^{\circ} \mathrm{C}$ [21] with Axopatch 200B amplifier (Molecular Devices Corporation, CA, USA) controlled by the ISO2 program (MFK, Germany). Electrophysiological recordings were not feasible when hMSC were attached to glass cover slips. Therefore, subconfluent hMSC were detached from small culture flasks with trypsin/EDTA [18]. After centrifugation at $88 \times g$ for 5 min cells were resuspended in culture medium. The suspension was stored at room temperature and used within $6 \mathrm{~h}$.

Electrophysiological recordings were carried out as described previously [18]. Briefly, cells were allowed to attach to the glass bottom of a small chamber and were superfused with buffer solution at a rate of $1.8 \mathrm{ml} / \mathrm{min}$. Patch electrodes were pulled with a horizontal puller (Zeitz, Germany) from filamented borosilicate glass. The tip resistance was 1.5-4.0 $\mathrm{M} \Omega$, when filled with electrode solution. Membrane capacitance was measured with fast depolarizing ramp pulses and compensated. Series resistance was routinely checked and compensated by $50-80 \%$. Membrane currents were low-pass filtered at $2 \mathrm{kHz}$.

Outward currents were recorded with the following bath solution (in $\mathrm{mM}$ ): $\mathrm{NaCl} 150, \mathrm{KCl} 5.4, \mathrm{CaCl}_{2} 2, \mathrm{MgCl}_{2}$ 2, glucose 11 and HEPES $10(\mathrm{pH} 7.4$ adjusted with $\mathrm{NaOH})$. The pipette solution included (in $\mathrm{mM}$ ): $\mathrm{NaCl} 8, \mathrm{KCl} 40$, K-aspartate 100, Tris-GTP 0.1, Mg-ATP 5, $\mathrm{CaCl}_{2}$ 2, EGTA 5 (pH adjusted to 7.3 with $\mathrm{KOH}$ ) resulting in a calculated free $\mathrm{Ca}^{2+}$ and $\mathrm{Mg}^{2+}$ concentration of $64 \mathrm{nM}$ and 587 $\mu \mathrm{M}$, respectively [22]. All membrane potentials were corrected for a calculated liquid junction potential of $12.5 \mathrm{mV}$ (JPCalc version 2.2 [23]). The stimulation frequency was $0.25 \mathrm{~Hz}$. The current amplitude was determined at the end of individual depolarizing steps.

The presence of functional $\mathrm{Ca}^{2+}$ channels was assessed with $\mathrm{Na}^{+}$-free external solution supplemented with $2 \mathrm{mM} \mathrm{Ca}^{2+}$ or 10 $\mathrm{mM} \mathrm{Ba}^{2+}$ under conditions described previously [24]. The L-type $\mathrm{Ca}^{2+}$ channel activator (-)-BayK8644 was used to facilitate current detection [25].

\section{Reverse transcription-polymerase chain reaction}

Total RNA $(0.5 \mu \mathrm{g})$ isolated by the guanidinium method [26] was reverse transcribed in a $21-\mu 1$ reaction mixture that contained $75 \mathrm{mM}$ $\mathrm{KCl}, 50 \mathrm{mM}$ Tris- $\mathrm{HCl}$ (pH 8.3), $3 \mathrm{mM} \mathrm{MgCl}, 0.5 \mathrm{mM}$ of each dATP, dCTP, dGTP, dTTP, $600 \mathrm{ng}$ of random hexamer primers, $10 \mathrm{mM}$ DTT, 2 U of RNAse inhibitor and $10 \mathrm{U}$ of Superscript RNase H- (In- 


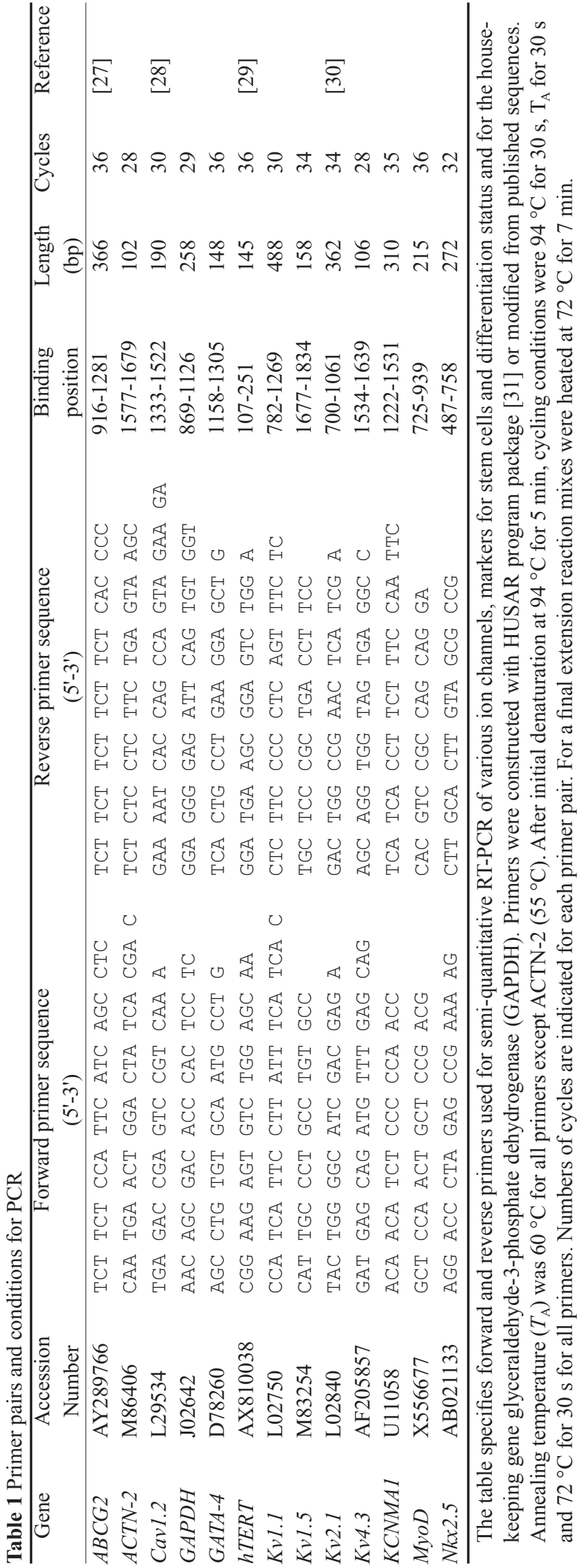

vitrogen, Germany) according to the manufacturer's instructions. $3 \mu 1$ aliquots of total cDNA were amplified (Mastercycler, Eppendorf, Germany) in a $25-\mu 1$ reaction mixture containing $50 \mathrm{mM} \mathrm{KCl}, 10$ $\mathrm{mM}$ Tris- $\mathrm{HCl}(\mathrm{pH} 8.3), 1.5 \mathrm{mM} \mathrm{MgCl}_{2}, 0.2 \mathrm{mM}$ of each dATP, dCTP, dGTP, dTTP, 25 pmol of each forward and reverse primer and $1.25 \mathrm{U}$ of Taq polymerase (Applied Biosystems, Germany; for primers and reaction conditions see Table 1). The same single-stranded cDNA product was used to analyse the expression of all genes described. To assure that amplification was in the exponential range, progress of PCR was determined by amplifying identical reaction mixtures for ascending numbers of cycles. After the cited number of PCR cycles, amplification rate was sufficient without reaching saturation for any of the amplicons. PCR products were resolved by $2 \%$ agarose gel electrophoresis and stained with ethidium bromide. Bands imaged by a CCD camera (Biostep, Germany) were analysed via optical densitometry with Phoretix 1D software (Biostep).

\section{Drugs}

(-)-BayK 8644 was obtained from Bayer, Germany. Clofilium tosylate was from Lilly (Indianapolis, IN, USA). Recombinant iberiotoxin was purchased form Alomone Labs, Israel. All other drugs and chemicals were acquired from Sigma (St Louis, MO, USA).

\section{Statistics}

Results are presented as mean values \pm S.E.M. The statistical differences between means of 2 groups were evaluated by the Student's $t$-test. A value of $p<0.05$ was considered statistically significant.

\section{Results}

\section{Characterization of mesenchymal stem cells}

hMSC could be successfully isolated and expanded in vitro. They are of elongated spindle shape closely resembling fibroblasts (Figure 1A).

\section{Expression of surface markers}

Flow-cytometric characterization of cells from 10 patients revealed that the majority of cells were positive for CD105 $(98.5 \pm 2.2 \%)$ and CD166 (98.9 $\pm 1.3 \%)$, and negative for CD45 $(1.3 \pm 1.6 \%)$ (means \pm S.D.). Since the identity of stem cells is still an issue [32] cells were also screened for other markers, though not in every individual patient. Cells were also positive for CD29, $99.8 \pm 0.2 \%$ (4 patients); CD44, $99.4 \pm 0.5 \%$ (3 patients); CD73, $98.8 \pm$ $1.3 \%$ (6 patients); CD 90, $92.3 \pm 5.6 \%$ (3 patients); whereas they were negative for $\mathrm{CD} 14,0.81 \pm 0.43 \%$ (7 patients) and CD34, $0.41 \pm 0.30 \%$ ( 6 patients).

\section{Expression of stem cell markers}

The hMSCs were negative for Oct $3 / 4$, which is an essential factor for maintaining unlimited self-renewal in embryonic stem cells. P19 embryonic carcinoma cells were used as a positive control (Figure 1C). On the other hand, the mRNA expression of the putative adult stem cell marker ABCG2, a multidrug transporter protein, was detected in our cells suggesting their multipotential character [33]. 
A

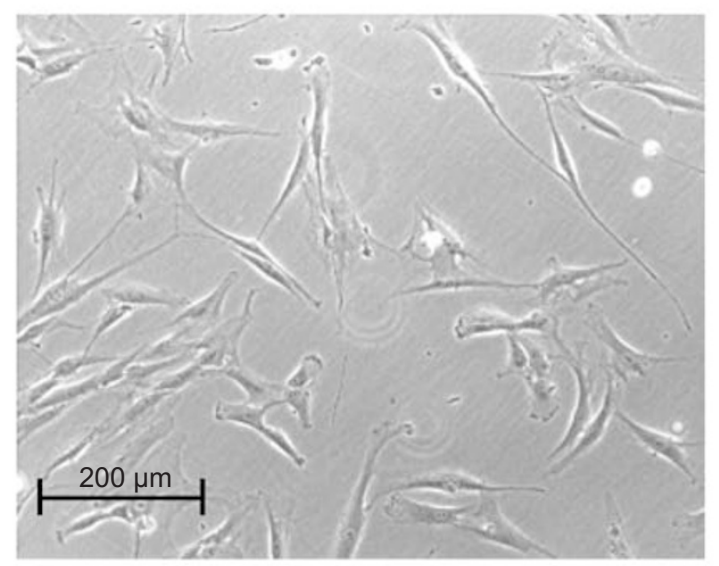

B

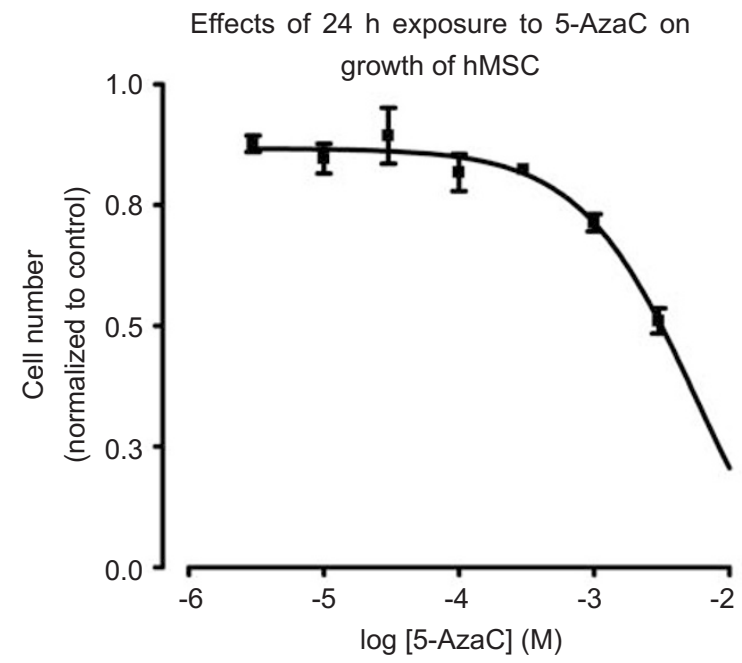

C
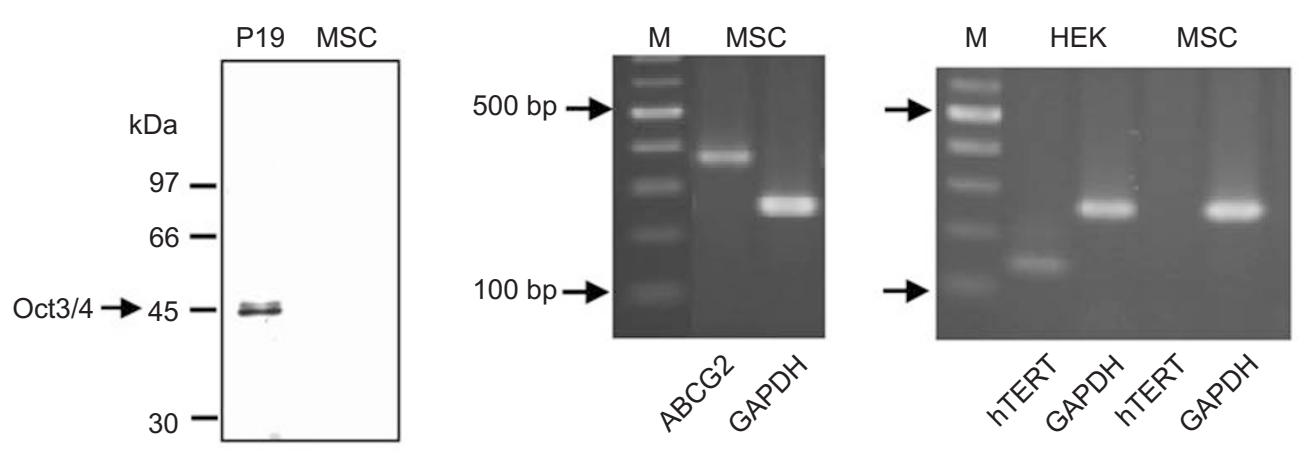

D
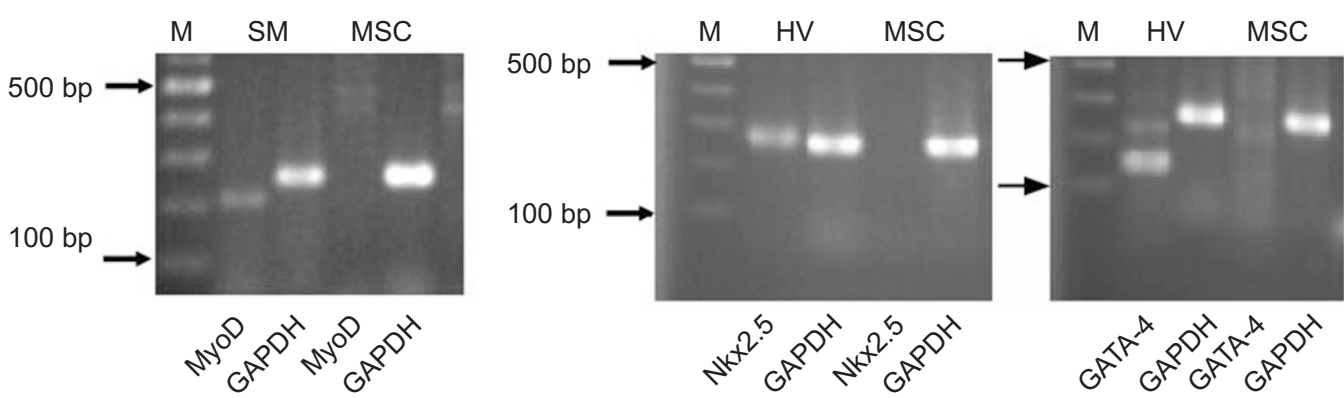

Figure 1 Characterization of hMSC cultures and toxic effects of 5-azacytidine. (A) Morphology of human MSC in culture. (B) Lack of significant toxicity upon $24 \mathrm{~h}$ exposure to micromolar concentrations of 5-azacytidine. Data represent mean values \pm S.E.M. from three independent experiments (each containing 2-3 wells for any given conditions). (C) Expression of various proteins and mRNAs. From left to right: Western blot of Oct3/4 protein from P19 cells and MSC; agarose gels of PCR-reaction products of the adult stem cell marker ABCG2 in hMSC; catalytic subunit of telomerase hTERT in HEK and hMSC cells. (D) Gels of PCR-reaction products of the myogenic marker MyoD in skeletal muscle (SM) and hMSC; cardiac transcription factors Nkx2.5 and GATA-4 in human ventricular tissue (HV) and hMSC. GAPDH was used as the housekeeping gene control. Protein molecular weight or PCR size markers are shown at the left of each panel. Arrows indicate $100 \mathrm{bp}$ (lower) and $500 \mathrm{bp}$ (upper) molecular weight marker bands (M).

The catalytic subunit of telomerase, hTERT, is a necessary component for telomerase activity [29] which is present in immortalized cells such as HEK (human embryonic kidney) cells, but was not expressed in hMSC. MyoD belongs to the family of basic helix-loop-helix transcription factors acting as a "master switch" during the differentiation of skeletal 
muscle [34]. While robust expression of MyoD was present in skeletal muscle tissue, none was detected in hMSC. Unlike human ventricular tissue that served as a positive control, hMSC did not express the cardiac transcription factors Nkx2.5 and GATA-4 (Figure 1D).

\section{Effects of 24 h of 5-azacytidine treatment on cell growth}

Cultures of hMSC were treated with various concentrations of 5-azacytidine over $24 \mathrm{~h}$. Next, their metabolic activity, an indicator of the number of viable cells, was determined using MTT assay and normalized to untreated, time-matched controls (Figure 1B). It is noticeable that 5azacytidine did not exhibit any significant acute toxicity in the micromolar range of concentrations, which were postulated to induce cardiogenesis $[9,14,15]$.

\section{Effects of 5-azacytidine on cell morphology and expression of cardiac structural proteins}

Cells from passages 1 to 3 were grown until they reached $70-85 \%$ confluence and were treated with 5-azacytidine $(3 \mu \mathrm{M})$ for $24 \mathrm{~h}$, the controls were left undisturbed. After medium change all cells were further cultured for additional 6 weeks without subculture. Untreated controls and 5azacytidine-treated cultures were analysed after 1, 2, 3, 4 and 6 weeks for changes in morphology and expression of markers of myogenic or cardiac differentiation such as transcription factors and structural proteins. All cells proliferated to reach confluence within one week - irrespective of whether they had been treated or not. The high cell density precluded detection of cross striations under light microscopy. Despite the absence of beating areas in any single one of the cultures, differentiation of hMSC into cardiomyocytes could not be excluded because these cells could have been quiescent. Untreated and 5-azacytidine-treated hMSC after 2 and 6 weeks were similar in morphology with a fibroblast-like appearance (data not shown). However, immunostaining for sarcomeric myosin heavy chain and cardiac troponin $\mathrm{T}$ could not be detected at any time irrespective of exposure to 5-azacytidine (data not shown).

\section{Effects of 5-azacytidine on mRNA expression of myogenic or cardiac markers}

Treatment of hMSC (1-3 passages) for $24 \mathrm{~h}$ with $3 \mu \mathrm{M}$ 5 -azacytidine did not induce differentiation into skeletal muscle-like cells as indicated by the lack of expression of MyoD (Figure 2). Neither did the treatment induce mRNA expression of the cardiogenic transcription factors Nkx2.5 (Figure 2) nor GATA-4 (data not shown). Also, expression of the cardiac isoform of $\alpha$-actinin encoded by ACTN-2 gene was not detected in either treated or control cells (Figure 2).

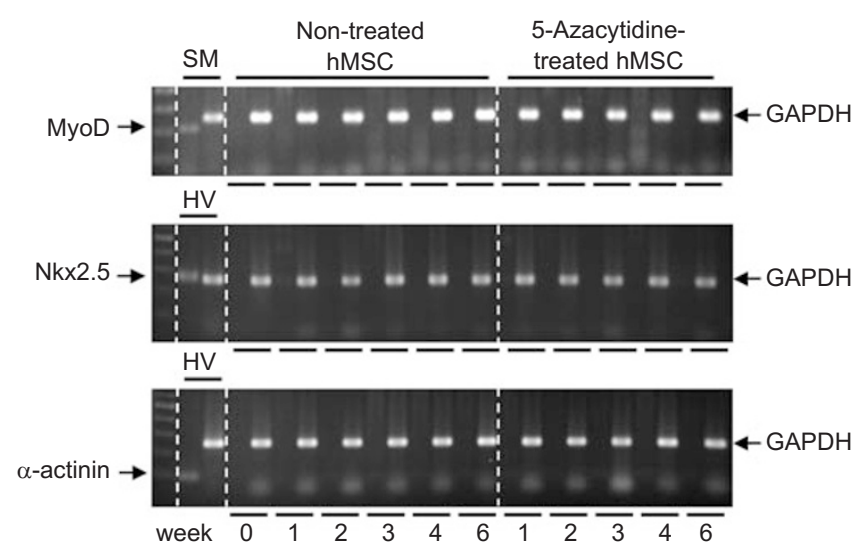

Figure 2 Lack of effects upon 24 h exposure to 5 -azacytidine $(3 \mu \mathrm{M})$ on expression of MyoD, Nkx2.5 and $\alpha$-actinin in hMSCs. Results are shown for controls (non-treated hMSC) and 5-azacytidine-treated hMSC during 6 weeks of culture. SM, skeletal muscle; HV, human ventricle.

Effects of 5-azacytidine on ion currents and expression of channel $m R N A$

In our previous study of undifferentiated hMSC, L-type $\mathrm{Ca}^{2+}$ currents $\left(I_{\mathrm{Ca}, \mathrm{L}}\right)$ were detected in about $10-15 \%$ of all cells; $\mathrm{Na}^{+}$currents were absent, and two delayed rectifier $\mathrm{K}^{+}$currents were characterized, one most likely representing the $\mathrm{Ca}^{2+}$-activated $\mathrm{Big} \mathrm{K} \mathrm{K}^{+}$channel [18]. Under control conditions we identified $I_{\mathrm{Ca}, \mathrm{L}}$ in a similar fraction of cells ( 4 out of 20 cells) with a mean current density of $-2.0 \pm$ $0.4 \mathrm{pA} / \mathrm{pF}$ at $0 \mathrm{mV}$ after stimulation with (-)-BayK 8644 $(1 \mu \mathrm{M})$. Two weeks after treatment with 5-azacytidine, $\mathrm{Ca}^{2+}$ current was detected in three cells out of 29 (mean current density $-2.3 \pm 0.4 \mathrm{pA} / \mathrm{pF}$ ) vs $0 / 13$ in control cells (data not shown). After 6 weeks $\mathrm{Ca}^{2+}$ current was not detected in both time-matched control and 5-azacytidine treated cells $(0 / 5$ vs $0 / 6$, respectively). Despite the small number of measured cells, we conclude that no major changes in $\mathrm{Ca}^{2+}$ current density took place after 5-azacytidine treatment. $I_{\mathrm{Na}}$ was absent. Outward currents recorded under control conditions (before beginning of the experiment) were of two distinct types (see Figure 3A): four out of 35 cells exhibited a potential-dependent rapidly activating current " $I_{\mathrm{r}}$ " (" $r$ " for rapid activation) with a threshold around $0 \mathrm{mV}$ and no inactivation. Characteristically, recordings at strongly positive potentials showed considerable noise. The current did not saturate and was partially blocked with $100 \mathrm{nM}$ iberiotoxin (data not shown), suggesting the current flows through $\mathrm{Ca}^{2+}$-activated $\mathrm{Big} \mathrm{K}^{+}$channels (MaxiK channels). Fourteen out of 35 cells studied exhibited a slowly activating potential-dependent current " $I_{\mathrm{s}}$ " (" $s$ " for 

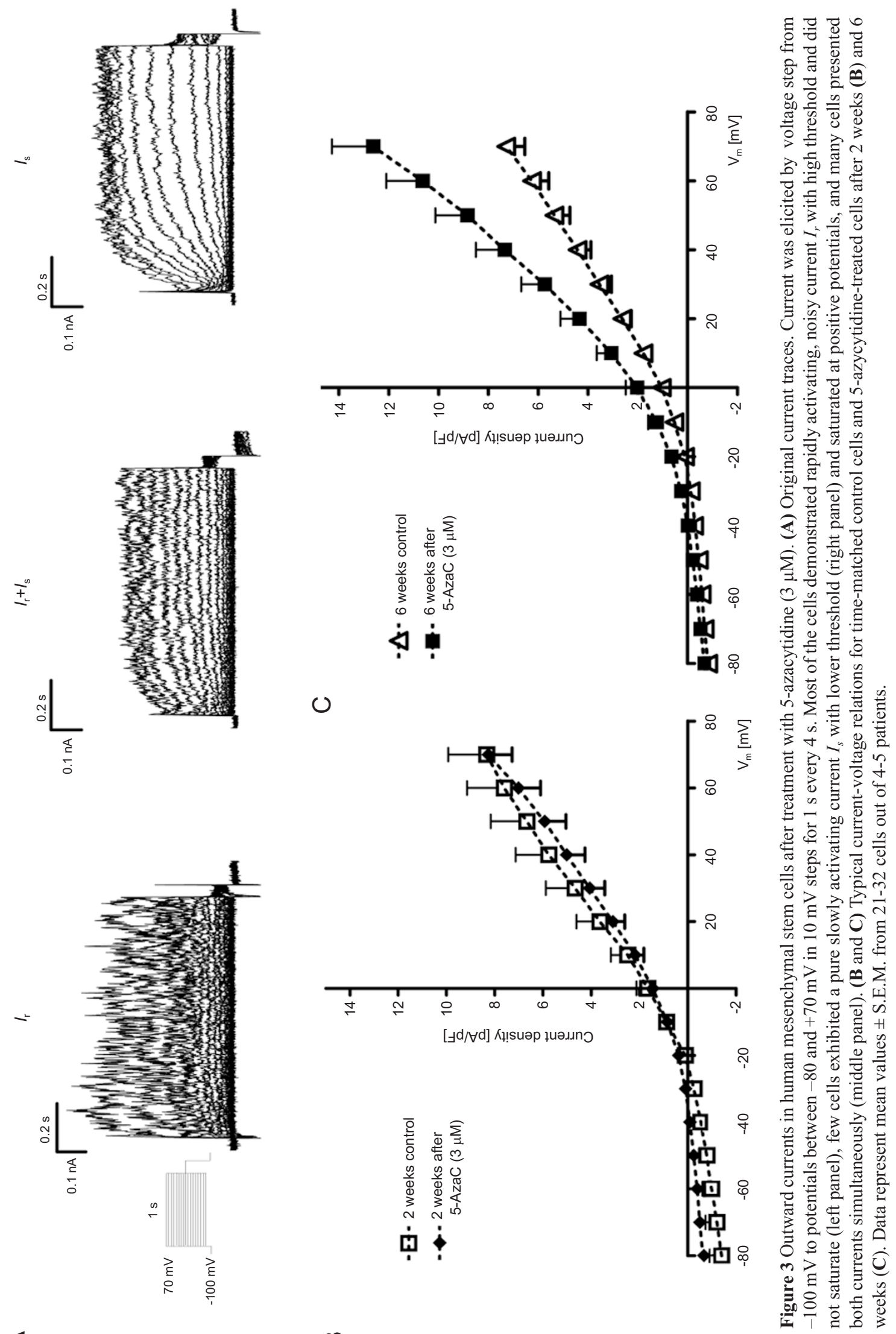

$\varangle$

๓ 
A
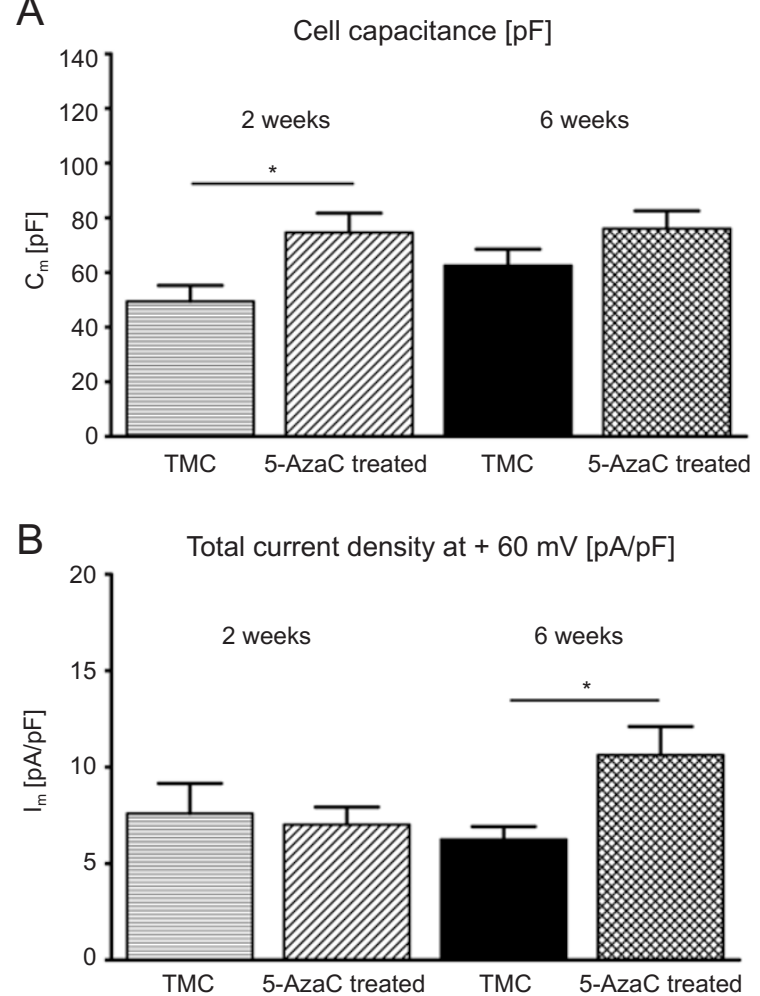

Figure 4 Effect of 5 -azacytidine treatment of hMSC $(3 \mu \mathrm{M})$ on mean values of cell capacitance (A) and current densities at +60 $\mathrm{mV}$ after 2 and 6 weeks (B). ${ }^{*} p<0.05$ vs time-matched control (TMC). Data represent mean values \pm S.E.M. from 21-32 cells out of 4-5 patients.

slow activation). This current had a threshold at $-40 \mathrm{mV}$, clearly saturated at potentials positive to $+60 \mathrm{mV}$ and was less noisy than $\mathrm{I}_{\mathrm{r}}$. Another 17 cells, however, exhibited a mixture of both current components. For comparison of the current-voltage relations, current amplitudes at the end of the clamp steps were normalized for individual cell size as indicated by cell capacitance and expressed as current density in $\mathrm{pA} / \mathrm{pF}$. Current density can be altered because of changes in current amplitude, in cell size or both. Two weeks after 5-azacytidine treatment the membrane capacitance was significantly larger than in control cells, but differences between treated and non-treated group disappeared after 6 weeks (Figure 4A). Next, we compared current density for different time points. Most cells analysed 2 and 6 weeks after treatment both in control and treated group displayed outward current with a mixture of $I_{\mathrm{r}}$ and $I_{\mathrm{s}}$. Therefore the current densities for a given time point were averaged regardless of current subtype. Mean $I-V$ curves for treated and untreated cells revealed no change of current density after 2 weeks (Figure 3B), but test pulses to $+60 \mathrm{mV}$ produced markedly increased current densities after 6 weeks in treated cells $(10.6 \pm 1.5 \mathrm{pA} / \mathrm{pF}$ vs $6.2 \pm$ $0.7 \mathrm{pA} / \mathrm{pF}$ (time-matched control) at $+60 \mathrm{mV}, p=0.0043$; Figure 4B).

Human MSC express mRNAs for several ion channel proteins, including $\alpha$-subunits for $\mathrm{K}^{+}$and $\mathrm{Ca}^{2+}$ selective voltage-activated ion channels $[18,48]$. Here we investigated whether 5-azacytidine treatment would influence the expression of mRNAs of selected ion channels. To this end, expression of the $\mathrm{K}^{+}$channels $\mathrm{Kv} 1.1, \mathrm{Kv} 1.5, \mathrm{Kv} 2.1, \mathrm{Kv} 4.3$ and KNCMA1 and for the $\mathrm{Ca}^{2+}$ channel $\mathrm{Ca}_{\mathrm{v}} 1.2$ was studied using RT-PCR (Figure 5). The expression levels of Kv1.1,

A

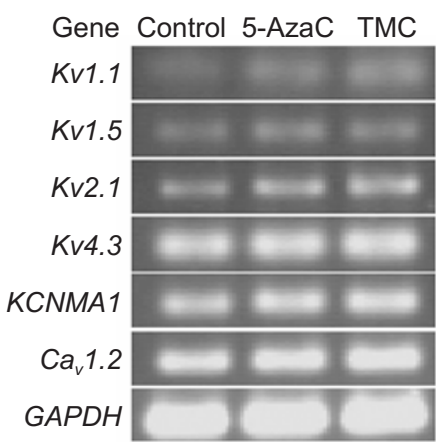

B

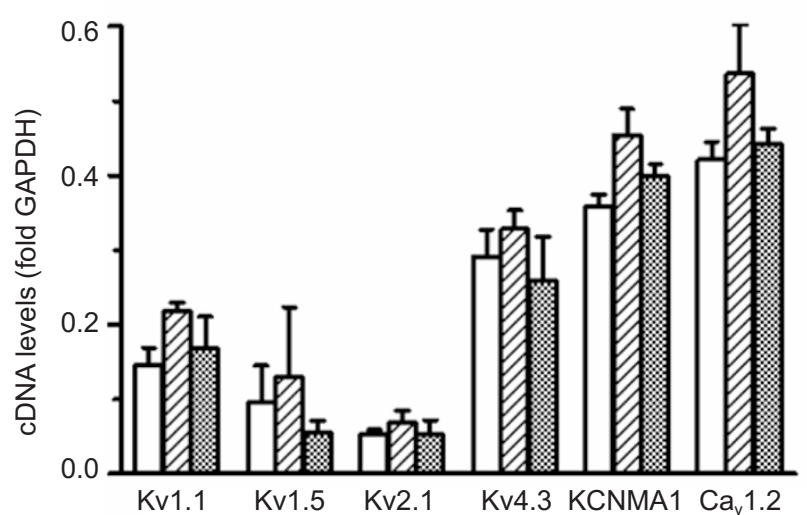

Figure 5 Effects of 5 -azacytidine treatment $(3 \mu \mathrm{M})$ on expression of mRNA of selected $\mathrm{K}^{+}$and $\mathrm{Ca}^{2+}$ channels in hMSC. (A) Representative agarose gels of RT-PCR products for Kv1.1, Kv1.5, Kv2.1, Kv4.3, $\mathrm{KCNMA} 1, \mathrm{Ca}_{\mathrm{v}} 1.2$ and the housekeeping gene GAPDH in hMSC (control), and in cells cultured for 6 weeks after treatment with $3 \mu \mathrm{M}$ 5 -azycytidine for 24 hours $(5-\mathrm{AzaC})$ and in time-matched controls (TMC) that did not receive treatment. (B) mRNA expression of the indicated channels normalized to GAPDH before (open columns), 6 weeks after treatment (hatched columns) and in TMC (dotted columns). Data represent mean values from three experiments with cells from three different patients. Please note that 5-azacytidine did not significantly affect mRNA expression of the examined channels. 

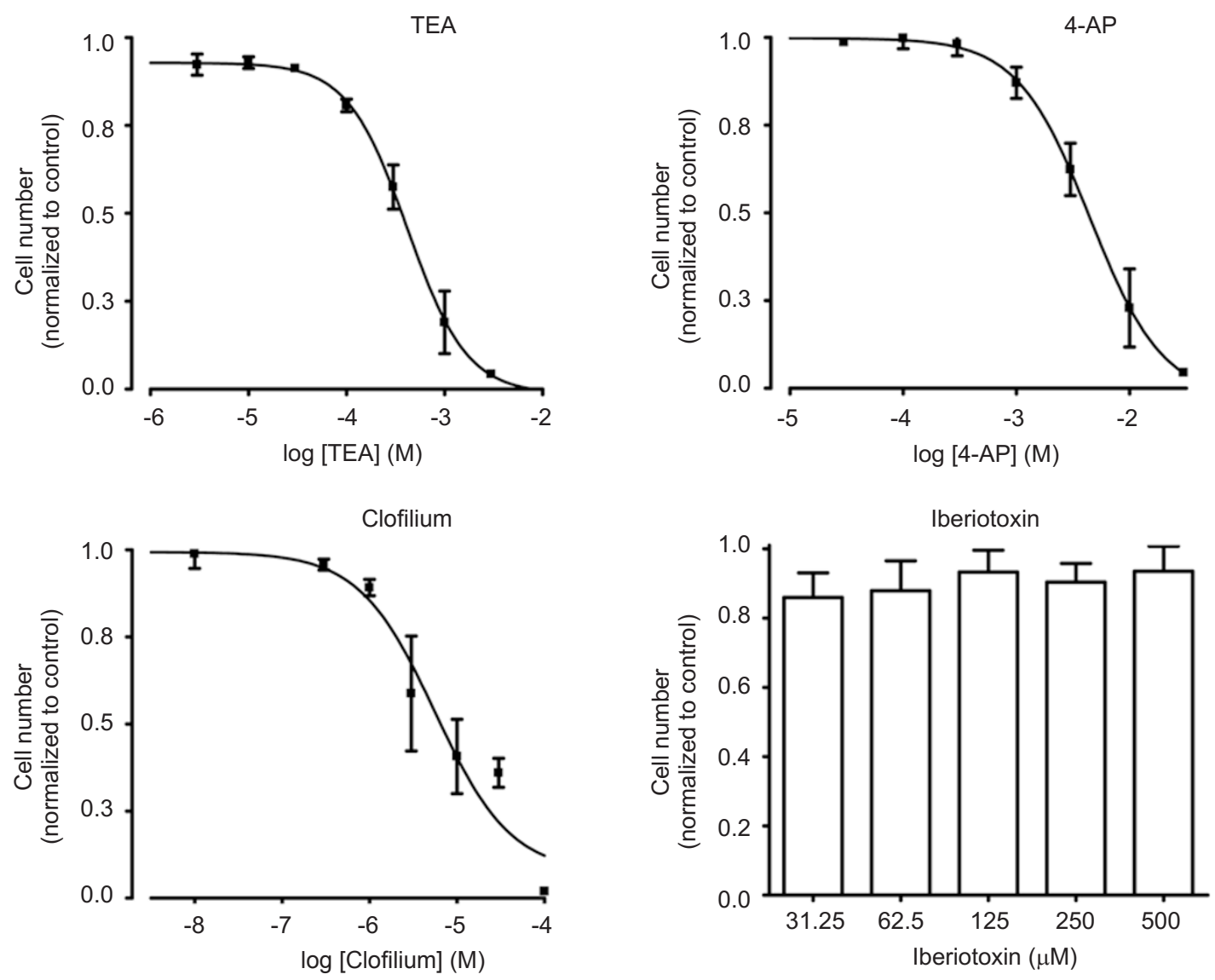

Figure 6 Effects of 7-day treatment with selected $\mathrm{K}^{+}$channel blockers on the growth of hMSC. Cultures were incubated for $7 \mathrm{~d}$ with TEA, 4-AP, clofilium or iberiotoxin. Growth was normalized to time-matched controls cultured with medium, where ion channel blockers were omitted. Data represent mean values \pm S.E.M. from three independent experiments (each containing 2-3 wells for any given conditions).

$\mathrm{Kv} 1.5, \mathrm{Kv} 2.1$ and $\mathrm{Ca}_{\mathrm{v}} 1.2$ were similar to those reported in our previous study, whereas Kv4.3 and KCNMA1 (Big $\mathrm{K}^{+}$channels) were expressed at somewhat lower levels, although the differences were not statistically significant [18]. The clear increase in outward current density 6 weeks after 5-azacytidine treatment (compare Figure 3 and 4) was not paralleled by a significantly enhanced expression level of any of the $\mathrm{K}^{+}$channels studied.

\section{Effects of selected potassium channel blockers on growth of $h M S C$}

Continued exposure for $7 \mathrm{~d}$ to TEA, 4-AP or clofilium but not to iberiotoxin decreased the number of viable cells in comparison to controls (TEA EC ${ }_{50}=417 \pm 191 \mu \mathrm{M}$; 4-AP $\mathrm{EC}_{50}=4.5 \pm 2.9 \mathrm{mM}$; clofilium $\mathrm{EC}_{50}=5.6 \pm 8.4 \mu \mathrm{M}$, Figure 6 ). The decrease in metabolic activity (cell number) could be either due to decrease in cell proliferation or direct toxic effects. As a 24-h exposure to TEA and clofilium did not affect the cell viability (data not shown), we suggest that specific block of potassium channels impairs cell cycle progression and hence proliferation.

\section{Discussion}

In the present study hMSC did not differentiate into cardiomyocytes within 6 weeks after a brief $24 \mathrm{~h}$ period of exposure to the DNA-methylation inhibitor 5-azacytidine. However, treatment with 5-azacytidine induced a significant increase in $\mathrm{K}^{+}$current density after 6 weeks.

\section{Characterization of the cells}

The donor-derived hMSC were positive for CD29, CD44, CD73, CD90, CD105 and CD166 surface markers and negative for the haematopoietic markers CD14, 
CD34 and CD45. Although there is no universal set of mesenchymal stem cell markers our results are in good agreement with the literatures. Pittenger et al. [6], for instance, defined human MSC as CD29, CD44, CD71, CD73, CD90, CD105, CD106, CD120a, CD124 positive and CD14, CD34, CD45 negative cells. Majumdar et al. [35] found that more than half of the human MSC isolated in their laboratory expressed CD13, CD29, CD44, CD49b, CD49e, CD54, CD71 and CD90.

Human MSC used in the present work did not express the transcription factor Oct3/4. This protein is involved in maintenance of the undifferentiated state of all embryonic pluripotent cell types and therefore represents a widely accepted marker of these cells [36]. However, its role in adult stem cells remains unclear. The expression of Oct $3 / 4$ was reported in a subpopulation of hMSC [37]. Although its presence would strongly suggests the uncommitted nature of the hMSC, there is no evidence that Oct $3 / 4$ is crucial for adult stem cells. The hMSC used here expressed mRNA encoded by the ABCG2 gene. This drug-extruding pump was initially detected on the surface of cancer cells and later suggested to be a common marker of adult stem cells [33]. The catalytic subunit of telomerase, hTERT, was not detected in our hMSC cultures, and hence it must be concluded that our cells also lack activity of this enzyme. Some groups reported expression and activity of telomerase in MSC $[6,38]$, while others could not detect the enzyme [39]. Interestingly, stable transfection with the telomerase gene led to immortalization of MSC without any influence on their differentiation potential [40]. These findings are in agreement with the hypothesis that adult stem cells have a limited proliferation potential which may be an element of protection against malignant transformation. However, it was suggested recently that self-renewal may not be an obligatory stem cell trait and plasticity alone defines stem state while other properties are optional [41]. The human MSC used in our experiments did not express the cardiacspecific transcription markers Nkx2.5 and GATA-4. Therefore, they cannot be regarded as cardiac progenitor cells like for instance the small population of human amnion-derived MSC that express GATA-4 [42].

\section{Mechanism of action of 5-azacytidine}

DNA methylation at the $\mathrm{C} 5$ atom of cytosine residues is a heritable and reversible epigenetic mechanism to regulate gene expression. For example, tissue-specific genes become silenced in many tissues, when they are methylated at the critical CpG sites in their promoters [43]. By forming covalent bonds with methyltransferase 5-azacytidine acts as an irreversible inhibitor of the enzyme [44]. This prevents methylation of DNA after cell division thereby reactivating transcription of genes previously silenced. 5-Azacytidine was repeatedly reported to induce differentiation of various selected adult stem cell populations into cardiomyocytes $[9,40,45,46]$.

\section{Evidence for cardiac differentiation}

5-Azacytidine treatment of mouse 10T1/2 fibroblasts originally led to the discovery of MyoD as a myogenic marker (for skeletal muscle) [8]; however, no expression of this marker was observed in our cells before or after 5azacytidine treatment. The cultures were negative for the cardiomyocyte markers, myosin heavy chain and cardiac troponin T. In addition, RT-PCR analysis did not reveal expression of mRNA for cardiac $\alpha$-actinin.

In the initial publication by Makino et al. [9], beating cardiomyocytes were formed after a single, 24-h 5-azacytidine treatment $(3 \mu \mathrm{M})$ of mouse bone marrow-derived MSC that had been immortalized by numerous subcultures. The beating cells and those surrounding them were subcloned and treated once more with 5-azacytidine. From these cultures, subclones of the most frequently beating cells were maintained as the cardiomyogenic cell line (CMG). These cells expressed cardiac transcription factors such as $\mathrm{Nkx} 2.5$, GATA-4, TEF-1 and MEF2-C, and could be stimulated in the cardiogenic direction with high efficiency (30\%) by 5 -azacytidine treatment. Our attempts to immortalize human MSC failed because the cells ceased to proliferate during prolonged culture (passage 12). Nevertheless, the human MSC were treated with 5-azacytidine but no beating was observed at any time nor were the cells stimulated to express the cardiac markers Nkx2.5 and GATA-4.

One reason for the failure of cardiac differentiation with $3 \mu \mathrm{M} 5$-azacytidine could be that the drug concentration used was too low. Some authors reported successful differentiation of hMSC with concentrations between 5 and $10 \mu \mathrm{M}[14,15]$, suggesting that human cells may require higher concentrations than their murine counterparts, possibly because of higher activity of cytidine deaminase which degrades 5-azacytidine [47]. It must be emphasized, however, that there are also reports of lack of differentiation in rat MSC even with concentrations of $10 \mu \mathrm{M} 5$-azacytidine [13]. Most likely, additional factors are required for successful differentiation. In a recently published study, $24 \mathrm{~h}$ treatment of a single clone of hMSC with $10 \mu \mathrm{M} 5$ azacytidine did not stimulate differentiation, but the same cells differentiated when co-cultured with neonatal cardiac cardiomyocytes and that effect was strongly enhanced by 5-azacytidine [40].

Effects of 5-azacytidine on electrophysiological properties of $h M S C$

We and others have shown previously that the majority of cultured hMSC possess delayed outwardly rectifying 
$\mathrm{K}^{+}$currents and between 10 and $15 \%$ of cells also display L-type $\mathrm{Ca}^{2+}$ current $[18,48]$. However, unlike Li et al. [48] we did not detect tetrodotoxin-sensitive $\mathrm{Na}^{+}$current. In spite of the failure to stimulate cardiogenic differentiation, 5-azacytidine treatment affected cell capacitance and current density of outwardly rectifying $\mathrm{K}^{+}$currents but did not change L-type $\mathrm{Ca}^{2+}$ currents.

Membrane capacitance is an estimate of cell surface and hence cell size. 5-Azacytidine treatment transiently (after 2 weeks) increased mean cell size over non-treated control. This difference was not statistically significant 6 weeks after exposure to the drug. In order to correct for cell size, absolute current amplitudes are generally expressed as current density, and 6 weeks after treatment, this value was nearly doubled, suggesting a profound increase in channel activity. Since mRNA expression of putative channels for this current (e.g. KCNMA1) was not significantly changed, either membrane incorporation or functional channel regulation must have been altered by the treatment.

The present results on ion channel pattern of hMSC are not different from but extend our previous findings [18] by suggesting that one physiological role of the potassium channel activity found in hMSC could be involvement in cell cycle. We determined that cell proliferation, measured as number of viable cells after a given period of time, is decreased by TEA at submillimolar concentration (a drug concentration that blocks MaxiK, Kv1.1, Kv3 and Kv7.2 channels $[49,50])$ and by micromolar concentration of clofilium (concentration effective to block HERG channels [51]). Significantly, we have previously shown that similar concentrations of TEA and clofilium inhibited $I_{\mathrm{r}}$ and $I_{\mathrm{s}}$, respectively [18]. This suggests association of channel activity with proliferation and cell cycle progression. It was shown in case of some cancer cells that potassium currents are coupled to the cell cycle progression. For instance, in the breast cancer cell line MCF-7, voltage-gated outward $\mathrm{K}^{+}$currents and large-conductance $\mathrm{Ca}^{2+}$-activated $\mathrm{K}^{+}$currents are upregulated in the G1 phase of the cell cycle $[52,53]$. Therefore, the increase of mean current density upon 5-azacytidine treatment described here may reflect higher numbers of dividing cells, especially since more cells exhibited large amplitude currents after 5 -azacytidine treatment than in time-matched controls, although direct effects of 5-azacytidine on proliferation of hMSC were not measured in the present study.

\section{Conclusion}

In the present study, we report that even a transient 24-h treatment with 5-azacytidine alters electrophysiological properties of hMSC, but does not induce their differentiation into cardiomyocytes. These findings suggest not only that hMSC are inhomogeneous with respect to their electrophysiological properties but also that changes in ion currents are not necessarily appropriate markers of cardiomyocyte differentiation. Sensitivity of growth of hMSC to potassium channel blockers suggests that the activity of channels may be associated with proliferation.

\section{Acknowledgments}

We gratefully acknowledge the excellent technical assistance of Annegret Häntzschel, Manja Schöne and Romy Kempe. This study was supported by a grant of the BMBF (German Federal Ministry of Education and Research, BioMeT Project 03I 4019).

\section{References}

1 Barry FP, Murphy JM. Mesenchymal stem cells: clinical applications and biological characterization. Int J Biochem Cell Biol 2004; 36:568-584.

2 Orlic D, Kajstura J, Chimenti S, Bodine DM, Leri A, Anversa P. Bone marrow cells regenerate infarcted myocardium. Nature 2001; 410:701-705.

3 Jackson KA, Majka SM, Wang H, et al. Regeneration of ischemic cardiac muscle and vascular endothelium by adult stem cells. J Clin Invest 2001; 107:1395-1402.

4 Strauer BE, Brehm M, Zeus T, et al. Repair of infarcted myocardium by autologous intracoronary mononuclear bone marrow cell transplantation in humans. Circulation 2002; 106:1913-1918.

5 Wollert KC, Drexler H. Clinical applications of stem cells for the heart. Circ Res 2005; 96:151-163.

6 Pittenger MF, Mackay AM, Beck SC, et al. Multilineage potential of adult human mesenchymal stem cells. Science 1999; 284:143147.

7 Taylor SM, Jones PA. Multiple new phenotypes induced in 10T1/2 and 3T3 cells treated with 5-azacytidine. Cell 1979; 17:771-779.

8 Konieczny SF, Emerson CP Jr. 5-Azacytidine induction of stable mesodermal stem cell lineages from 10T1/2 cells: evidence for regulatory genes controlling determination. Cell 1984; 38:791800.

9 Makino S, Fukuda K, Miyoshi S, et al. Cardiomyocytes can be generated from marrow stromal cells in vitro. J Clin Invest 1999; 103:697-705.

10 Boheler KR, Czyz J, Tweedie D, Yang HT, Anisimov SV, Wobus AM. Differentiation of pluripotent embryonic stem cells into cardiomyocytes. Circ Res 2002; 91:189-201.

11 Maltsev VA, Wobus AM, Rohwedel J, Bader M, Hescheler J. Cardiomyocytes differentiated in vitro from embryonic stem cells developmentally express cardiac-specific genes and ionic currents. Circ Res 1994; 75:233-244.

12 Wobus AM, Wallukat G, Hescheler J. Pluripotent mouse embryonic stem cells are able to differentiate into cardiomyocytes expressing chronotropic responses to adrenergic and cholinergic agents and $\mathrm{Ca}^{2+}$ channel blockers. Differentiation 1991; 48:173182.

13 Liu Y, Song J, Liu W, Wan Y, Chen X, Hu C. Growth and dif- 
ferentiation of rat bone marrow stromal cells: does 5-azacytidine trigger their cardiomyogenic differentiation? Cardiovasc Res $2003 ; \mathbf{5 8}: 460-468$.

$14 \mathrm{Xu} \mathrm{W,} \mathrm{Zhang} \mathrm{X,} \mathrm{Qian} \mathrm{H,} \mathrm{et} \mathrm{al.} \mathrm{Mesenchymal} \mathrm{stem} \mathrm{cells} \mathrm{from}$ adult human bone marrow differentiate into a cardiomyocyte phenotype in vitro. Exp Biol Med (Maywood) 2004; 229:623631.

15 Cao F, Niu LL, Meng L, et al. Cardiomyocyte-like differentiation of human bone marrow mesenchymal stem cells after exposure of 5-azacytidine in vitro. Shi Yan Sheng Wu Xue Bao 2004; 37:118-124.

16 Balana B, Nicoletti C, Zahanich I, et al. 5-Azacytidine treatment of mesenchymal stem cells influences potassium outward current density, but does not trigger cardiac differentiation. NaunynSchmiedeberg's Arch Pharmacol 2005; 371(Suppl 1):R16.

17 World Medical Association. World Medical Association Declaration of Helsinki. Ethical principles for medical research involving human subjects. Nurs Ethics 2002; 9:105-109.

18 Heubach JF, Graf EM, Leutheuser J, et al. Electrophysiological properties of human mesenchymal stem cells. J Physiol (London) 2004; 554:659-672.

19 Bruder SP, Jaiswal N, Haynesworth SE. Growth kinetics, selfrenewal, and the osteogenic potential of purified human mesenchymal stem cells during extensive subcultivation and following cryopreservation. J Cell Biochem 1997; 64:278-294.

20 Dieckmann-Schuppert A, Schnittler HJ. A simple assay for quantification of protein in tissue sections, cell cultures, and cell homogenates, and of protein immobilized on solid surfaces. Cell Tissue Res 1997; 288:119-126.

21 Hamill OP, Marty A, Neher E, Sakmann B, Sigworth FJ. Improved patch-clamp techniques for high-resolution current recording from cells and cell-free membrane patches. Pflugers Arch 1981; 391:85-100.

22 Fabiato A, Fabiato F. Calculator programs for computing the composition of the solutions containing multiple metals and ligands used for experiments in skinned muscle cells. J Physiol (Paris) 1979; 75:463-505.

23 Barry PH. JPCalc, a software package for calculating liquid junction potential corrections in patch-clamp, intracellular, epithelial and bilayer measurements and for correcting junction potential measurements. J Neurosci Methods 1994; 51:107-116.

24 Heubach JF, Köhler A, Wettwer E, Ravens U. T-type and tetrodotoxin-sensitive $\mathrm{Ca}^{2+}$ currents coexist in guinea pig ventricular myocytes and are both blocked by mibefradil. Circ Res 2000; 86:628-635.

25 Bechem M, Schramm M. Calcium-agonists. J Mol Cell Cardiol 1987; 19(Suppl 2):63-75.

26 Chomczynski P, Sacchi N. Single-step method of RNA isolation by acid guanidinium thiocyanate-phenol-chloroform extraction. Anal Biochem 1987; 162:156-159.

27 Katz AJ, Tholpady A, Tholpady SS, Shang H, Ogle RC. Cell surface and transcriptional characterization of human adiposederived adherent stromal (hADAS) cells. Stem Cells 2005; 23:412-423.

28 Grammer JB, Bosch RF, Kühlkamp V, Seipel L. Molecular and electrophysiological evidence for "remodeling" of the L-type $\mathrm{Ca}^{2+}$ channel in persistent atrial fibrillation in humans. Z Kardiol 2000; 89(Suppl 4):IV/23-IV/29.

29 Nakamura TM, Morin GB, Chapman KB, et al. Telomerase catalytic subunit homologs from fission yeast and human. Science 1997; 277:955-959.

30 Postma AV, Bezzina CR, de Vries JF, Wilde AA, Moorman AF, Mannens MM. Genomic organisation and chromosomal localisation of two members of the KCND ion channel family, KCND2 and KCND3. Hum Genet 2000; 106:614-619.

31 Senger M, Flores T, Glatting K Ernst P, Hotz-Wagenblatt A, Suhai S. W2H: WWW interface to the GCG sequence analysis package. Bioinformatics 1998; 14:452-457.

32 Perez-Iratxeta C, Palidwor G, Porter CJ, et al. Study of stem cell function using microarray experiments. FEBS Lett 2005; 579:1795-1801

33 Alison MR. Tissue-based stem cells: ABC transporter proteins take centre stage. J Pathol 2003; 200:547-550.

34 Lassar A, Münsterberg A. Wiring diagrams: regulatory circuits and the control of skeletal myogenesis. Curr Opin Cell Biol 1994; 6:432-442

35 Majumdar MK, Banks V, Peluso DP, Morris EA. Isolation, characterization, and chondrogenic potential of human bone marrow-derived multipotential stromal cells. J Cell Physiol 2000; 185:98-106.

36 Niwa H, Miyazaki J, Smith AG. Quantitative expression of Oct$3 / 4$ defines differentiation, dedifferentiation or self-renewal of ES cells. Nat Genet 2000; 24:372-376.

37 Pochampally RR, Smith JR, Ylostalo J, Prockop DJ. Serum deprivation of human marrow stromal cells (hMSCs) selects for a subpopulation of early progenitor cells with enhanced expression of OCT-4 and other embryonic genes. Blood 2004; 103:1647-1652.

38 Parsch D, Fellenberg J, Brummendorf TH, Eschlbeck AM, Richter W. Telomere length and telomerase activity during expansion and differentiation of human mesenchymal stem cells and chondrocytes. J Mol Med 2004; 82:49-55.

39 Zimmermann S, Voss M, Kaiser S, Kapp U, Waller CF, Martens UM. Lack of telomerase activity in human mesenchymal stem cells. Leukemia 2003; 17:1146-1149.

40 Takeda Y, Mori T, Imabayashi H, et al. Can the life span of human marrow stromal cells be prolonged by bmi-1, E6, E7, and/or telomerase without affecting cardiomyogenic differentiation? J Gene Med 2004; 6:833-845.

41 Zipori D. The stem state: plasticity is essential, whereas selfrenewal and hierarchy are optional. Stem Cells 2005; 23:719726.

42 Zhao P, Ise H, Hongo M, Ota M, Konishi I, Nikaido T. Human amniotic mesenchymal cells have some characteristics of cardiomyocytes. Transplantation 2005; 79:528-535.

43 Razin A, Kantor B. DNA methylation in epigenetic control of gene expression. Prog Mol Subcell Biol 2005; 38:151-167.

44 Taylor SM, Jones PA. Mechanism of action of eukaryotic DNA methyltransferase. Use of 5-azacytosine-containing DNA. J Mol Biol 1982; 162:679-692.

$45 \mathrm{Oh} \mathrm{H}$, Bradfute SB, Gallardo TD, et al. Cardiac progenitor cells from adult myocardium: homing, differentiation, and fusion after infarction. Proc Natl Acad Sci USA 2003; 100:12313-12318.

46 Rangappa S, Fen C, Lee EH, Bongso A, Sim EK. Transformation of adult mesenchymal stem cells isolated from the fatty tissue into cardiomyocytes. Ann Thorac Surg 2003; 75:775-779.

47 Chabner BA, Drake JC, Johns DG. Deamination of 5-azacytidine by a human leukemia cell cytidine deaminase. Biochem 
Pharmacol 1973; 22:2763-2765.

48 Li GR, Sun H, Deng X, Lau CP. Characterization of ionic currents in human mesenchymal stem cells from bone marrow. Stem Cells 2005; 23:371-382.

49 Goldberg JA, Wilson CJ. Control of spontaneous firing patterns by the selective coupling of calcium currents to calcium-activated potassium currents in striatal cholinergic interneurons. J Neurosci 2005; 25 :10230-10238.

50 Rudy B, McBain CJ. Kv3 channels: voltage-gated $\mathrm{K}^{+}$channels designed for high-frequency repetitive firing. Trends Neurosci 2001; 24: 517-526.
51 Gessner G, Heinemann SH. Inhibition of hEAG1 and hERG1 potassium channels by clofilium and its tertiary analogue LY97241. Br J Pharmacol 2003; 138:161-171.

52 Ouadid-Ahidouch H, Le Bourhis X, Roudbaraki M, Toillon RA, Delcourt P, Prevarskaya N. Changes in the $\mathrm{K}^{+}$current-density of MCF-7 cells during progression through the cell cycle: possible involvement of a h-ether.a-gogo $\mathrm{K}^{+}$channel. Receptors Channels 2001; 7:345-356.

53 Ouadid-Ahidouch H, Roudbaraki M, Ahidouch A, Delcourt P, Prevarskaya N. Cell-cycle-dependent expression of the large $\mathrm{Ca}^{2+}$-activated $\mathrm{K}^{+}$channels in breast cancer cells. Biochem Biophys Res Commun 2004; 316:244-251. 